Review

\title{
Biomineralization of Polychaete Annelids in the Fossil Record
}

\author{
Olev Vinn \\ Department of Geology, University of Tartu, Ravila 14A, 50411 Tartu, Estonia; olev.vinn@ut.ee; Tel.: +372-5067728 \\ Received: 31 August 2020; Accepted: 25 September 2020; Published: 29 September 2020

\begin{abstract}
Ten distinct microstructures occur in fossil serpulids and serpulid tubes can contain several layers with different microstructures. Diversity and complexity of serpulid skeletal structures has greatly increased throughout their evolution. In general, Cenozoic serpulid skeletal structures are better preserved than Mesozoic ones. The first complex serpulid microstructures comparable to those of complex structures of molluscs appeared in the Eocene. The evolution of serpulid tube microstructures can be explained by the importance of calcareous tubes for serpulids as protection against predators and environmental disturbances. Both fossil cirratulids and sabellids are single layered and have only spherulitic prismatic tube microstructures. Microstructures of sabellids and cirratulids have not evolved since the appearance of calcareous species in the Jurassic and Oligocene, respectively. The lack of evolution in sabellids and cirratulids may result from the unimportance of biomineralization for these groups as only few species of sabellids and cirratulids have ever built calcareous tubes.
\end{abstract}

Keywords: biominerals; calcite; aragonite; skeletal structures; serpulids; sabellids; cirratulids; evolution

\section{Introduction}

Among polychaete annelids, calcareous tubes are known in serpulids, cirratulids and sabellids [1-3]. The earliest serpulids and sabellids are known from the Permian [4], and cirratulids from the Oligocene [5]. Only serpulids dwell exclusively within calcareous tubes. Polychaete annelids build their tubes from calcite, aragonite or a mixture of both polymorphs. Calcareous polychaete tubes possess a variety of ultrastructural fabrics, from simple to complex, some being unique to annelids [1]. Serpulid tubes are usually single layered or composed of two layers, but some species have multiple tube layers [1,6-10]. Modern calcareous sabellid tubes can have two layers with distinct microstructures [2]. The microstructure of cirratulid tubes does not change through the tube wall [3]. Tube microstructures of modern polychaete annelids are relatively well known [1-3,11], but much less is known about the tube ultrastructures of fossil polychaetes [3,7,12-23]. Similarly, the mineralogy of modern calcareous polychaetes is in general well studied $[1,24,25]$, but there are few data available on the mineral composition of fossil material $[21,24]$. Nevertheless, available data on the tube microstructures and mineral composition of fossil calcareous polychaetes allow us to hypothesize about the evolution of polychaete biomineralization. Fossil material also enables us to verify the models of evolution of polychaete biomineralization based on studies of recent taxa and their phylogenetic analysis. All published skeletal microstructures of fossil polychaetes were included in this review. The aim of the present paper is to review known mineral microstructes and mineral compositions of fossil calcareous polychaetes and to hypothesize about the evolution of polychaete biomineralization.

\section{Materials and Methods}

All below illustrated sections of serpulid tubes were polished and etched in a $1 \%$ solution of acetic acid for $1 \mathrm{~min}$. All preparations were gold sputtered prior to Scanning Electron Microscope (SEM) 
investigation. SEM studies were performed on a Hitachi S-4300 SEM, equipped with an Inca Energy Dispersive X-Ray Analysis (EDX) system, at the Swedish Museum of Natural History, Stockholm. The beam was operated at $5-10 \mathrm{kV}$ and $1 \mathrm{nA}$.

\section{Biomineralization of Fossil Serpulids}

\subsection{Skeletal Structures}

Weedon [14] described results of serpulid tube secretion: "the structure consists of convex forward lamellae or chevrons. These lamellae are laid down successively from the anterior (apertural end) of the tube, being sub-parallel to the surface of the tube only near the inner and outer surfaces, and curving round as a convex-forward layer, wrapping the aperture of the tube." In addition to chevron shaped growth, lamellae serpulid tubes can contain microstructural zones or layers parallel to the tube surface. The majority of fossil serpulid tubes are single layered, but two layered tubes are also very common. Fossil serpulid tube layers always have distinct microstructures. In case of two layered tubes, all chevron shaped growth lamellae are composed of two different microstructures. Two layered tubes appeared already in the Jurassic [20]. Usually, the external tube layers of two layered tubes have spherulitic prismatic structure, whereas internal tube layers tend to have fine homogeneous granular structure $[18,20]$. Spherulitic prismatic structures and fine homogeneous granular structures are also among the most common fossil serpulid microstructures [18,20]. Ten distinct microstructures occur in fossil serpulids (Table 1). Fossil serpulid tube microstructures are here classified according to the orientation of structural elements and the complexity of structure, mostly based on Vinn et al.'s [1] classification for recent serpulid tube microstructures.

Table 1. Microstructures of fossil calcareous polychaetes.

\begin{tabular}{|c|c|c|c|}
\hline Species & Age & Microstructure & References \\
\hline Neovermilia falcigera & Pleistocene & Irregularly oriented platy structure & [1] \\
\hline Spirorbis corallinae & Pleistocene & Homogeneous granular structure & [12] \\
\hline Spirorbis spirorbis & Pleistocene & Homogeneous granular structure & [12] \\
\hline Ditrupa brevis & Pliocene & $\begin{array}{l}\text { Regularly ridged prismatic structure? (1); } \\
\text { Irregularly oriented prismatic structure? (2) }\end{array}$ & [13] \\
\hline Ditrupa gracillima & Miocene & $\begin{array}{l}\text { Regularly ridged prismatic structure (1); } \\
\text { fine homogeneous granular structure (2) }\end{array}$ & [22] \\
\hline Hydroides elegans & Miocene & $\begin{array}{l}\text { Fine homogeneous granular structure (1); } \\
\text { lamello-fibriallar structure? }(2)\end{array}$ & [18] \\
\hline Placostegus polymorphus & Miocene & Simple prismatic structure & [18] \\
\hline Pomatoceros sp. & Miocene & Lamello-fibrillar structure & [18] \\
\hline Protula canavarii & Miocene & Irregularly oriented prismatic structure & [18] \\
\hline Serpula muricata & Miocene & Irregularly oriented prismatic structure & [18] \\
\hline Spiraserpula sp. & Miocene & Lamello-fibrillar structure & [18] \\
\hline Diplochaetetes mexicanus & Oligocene & $\begin{array}{c}\text { Spherulitic } \\
\text { prismatic structure; homogeneous structure } \\
\text { composed of unoriented calcareous rods }\end{array}$ & [3] \\
\hline Serpula sp. & Oligocene & Irregularly oriented prismatic structure & [18] \\
\hline Ditrupa bartonensis & Eocene & $\begin{array}{l}\text { Regularly ridged prismatic structure (1); } \\
\text { simple preferentially orientated prismatic structure (2) }\end{array}$ & [23] \\
\hline Ditrupa strangulata & Eocene & $\begin{array}{l}\text { Regularly ridged prismatic structure (1); } \\
\text { fine homogeneous granular structure (2) }\end{array}$ & [22] \\
\hline
\end{tabular}


Table 1. Cont.

\begin{tabular}{|c|c|c|c|}
\hline Species & Age & Microstructure & References \\
\hline Protula protensa & Eocene & Semi-ordered irregularly oriented prismatic structure & [18] \\
\hline Pyrgopolon mellevillei? & Eocene & $\begin{array}{c}\text { Spherulitic } \\
\text { prismatic structure (1); } \\
\text { irregularly oriented prismatic structure (2) }\end{array}$ & [18] \\
\hline Rotularia nummularia & Eocene & $\begin{array}{l}\text { Coarse angular } \\
\text { crystal homogeneous structure (1); } \\
\text { lamello-fibrillar structure (2) }\end{array}$ & [19] \\
\hline Rotularia spirulaea & Eocene & $\begin{array}{l}\text { Coarse angular } \\
\text { crystal homogeneous structure (1); } \\
\text { lamello-fibrillar structure(2) }\end{array}$ & [19] \\
\hline Glomerula sp. & Cretaceous & Spherulitic prismatic structure & [2] \\
\hline Pentaditrupa subtorquata & Cretaceous & $\begin{array}{c}\text { Spherulitic } \\
\text { prismatic structure }\end{array}$ & [16] \\
\hline Pyrgopolon sp. A & Jurassic/Cretaceous & Prismatic (1); fine homogeneous granular structure (2) & [26] \\
\hline $\begin{array}{l}\text { Pyrgopolon aff. } \\
\text { nodulosum }\end{array}$ & Jurassic/Cretaceous & Prismatic (1); fine homogeneous granular structure (2) & [26] \\
\hline Filogranula tricristata & Jurassic & $\begin{array}{c}\text { Coarse angular } \\
\text { crystal homogeneous structure }\end{array}$ & [20] \\
\hline Glomerula sp. & Jurassic & $\begin{array}{c}\text { Spherulitic } \\
\text { prismatic structure }\end{array}$ & [2] \\
\hline $\begin{array}{l}\text { Mucroserpula } \\
\text { quinquangularis }\end{array}$ & Jurassic & $\begin{array}{c}\text { Spherulitic } \\
\text { prismatic structure (1); } \\
\text { fine homogeneous granular structure (2) }\end{array}$ & [16] \\
\hline Nogrobs cf. vertebralis & Jurassic & $\begin{array}{c}\text { Spherulitic } \\
\text { prismatic structure }\end{array}$ & [20] \\
\hline Propomatoceros sp. & Jurassic & Fine homogeneous granular structure & [14] \\
\hline Serpula conformis & Jurassic & Fine homogeneous granular structure & [20] \\
\hline Serpula aff. convoluta & Jurassic & Simple prismatic structure & [20] \\
\hline Serpula etalensis & Jurassic & Aragonitic irregularly oriented prismatic structure & [21] \\
\hline Serpula limata & Jurassic & Fine homogeneous granular structure & [20] \\
\hline Serpula aff. subcrispa & Jurassic & Fine homogeneous granular structure & [20] \\
\hline Serpula aff. trigona & Jurassic & $\begin{array}{l}\text { Spherulitic prismatic structure (1); } \\
\text { fine homogeneous granular structure (2) }\end{array}$ & [20] \\
\hline $\begin{array}{l}\text { Tetraserpula } \\
\text { planorbiformis }\end{array}$ & Jurassic & Simple prismatic structure & [20] \\
\hline
\end{tabular}

(1) External layer; (2) Inner layer. "?": indicate somewhat doubtful identifications.

\subsubsection{Unoriented Structures (Crystallization Axis Lacks Uniform Orientation)}

(1) The fine homogeneous granular structure is composed of small carbonate crystals of varying size and morphology. This structure is one of the most common fossil serpulid microstructures (Figure 1A).

(2) The coarse angular crystal homogeneous microstructure is usually composed of crystals 20-80 $\mu \mathrm{m}$ in diameter, which are lacking orientation [20] (Figure 1B).

(3) The irregularly oriented prismatic structure (IOP) is composed of elongated crystals of prismatic shape, which are irregularly oriented within each growth increment [1] (Figure 1C).

(4) The irregularly oriented platy structure (IOPL) is composed of slightly elongated crossing crystal platelets that are irregularly oriented within each growth increment [1]. It has a substructure that is composed of elongate slender prismatic crystallites, oriented subparallel with the longitudinal axis of crystals forming the IOPL structure [1] (Figure 1D). 

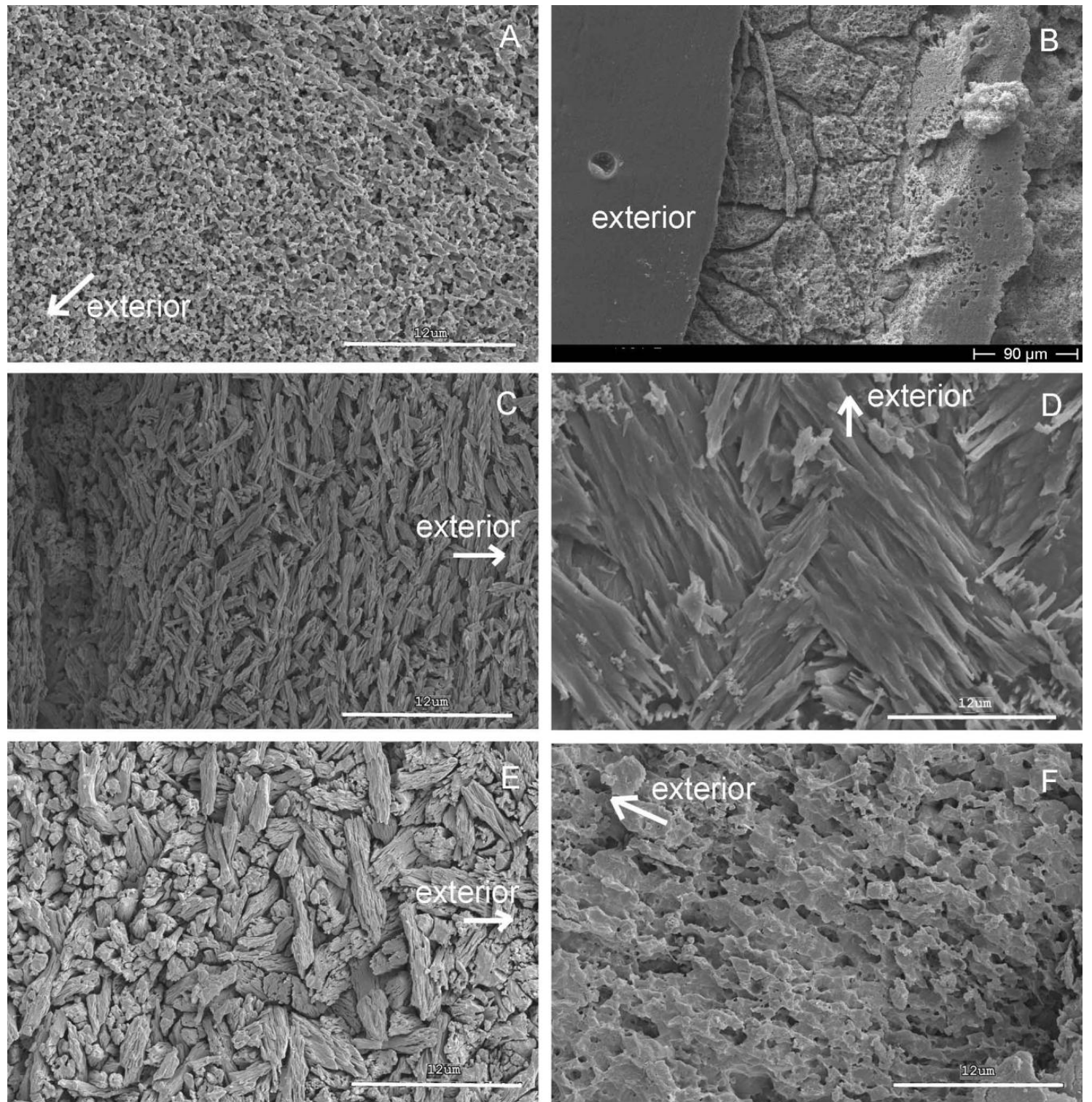

Figure 1. (A) Hydroides elegans from the Miocene of Austria, longitudinal section of external tube layer with a fine homogeneous granular structure. (B) Longitudinal section of coarse angular crystal homogeneous microstructure in Filogranula tricristata from the Bajocian of Switzerland. (C) Longitudinal section of irregularly oriented prismatic structure (IOP) in Protula canavarii (Miocene, Austria). (D) Transverse section of the irregularly oriented platy (IOPL) in Neovermilia falcigera from the Pleistocene of Italy. (E) Longitudinal section of semi-ordered IOP structure in Protula protensa (Upper Eocene). (F) Transverse section of simple prismatic structure in Placostegus polymorphus from the Miocene of Austria (arrow indicates orientation of prisms).

\subsubsection{Semi-Oriented Structures (The Crystallization Axis Has a Semi-Uniform Orientation)}

(5) The semi-ordered IOP structure [1] is composed of prismatic crystallites, which in general are irregularly oriented but have a tendency to have longitudinal axes oriented more sub-parallel or parallel to the tube surface [18] (Figure 1E). 
3.1.3. Oriented Prismatic Structures (The Crystallization Axis Has a Uniform Orientation, and Is Continuous Through Successive Growth Lamellae)

(6) The simple prismatic structure is formed by parallel prismatic crystals oriented perpendicularly to the tube wall of serpulids [1] (Figure 1F).

(7) The irregular spherulitic prismatic structure sensu Carter et al. [27] is formed by prismatic crystals of slightly spherulitic arrangement, oriented perpendicularly to the tube wall [1] (Figure 2A).
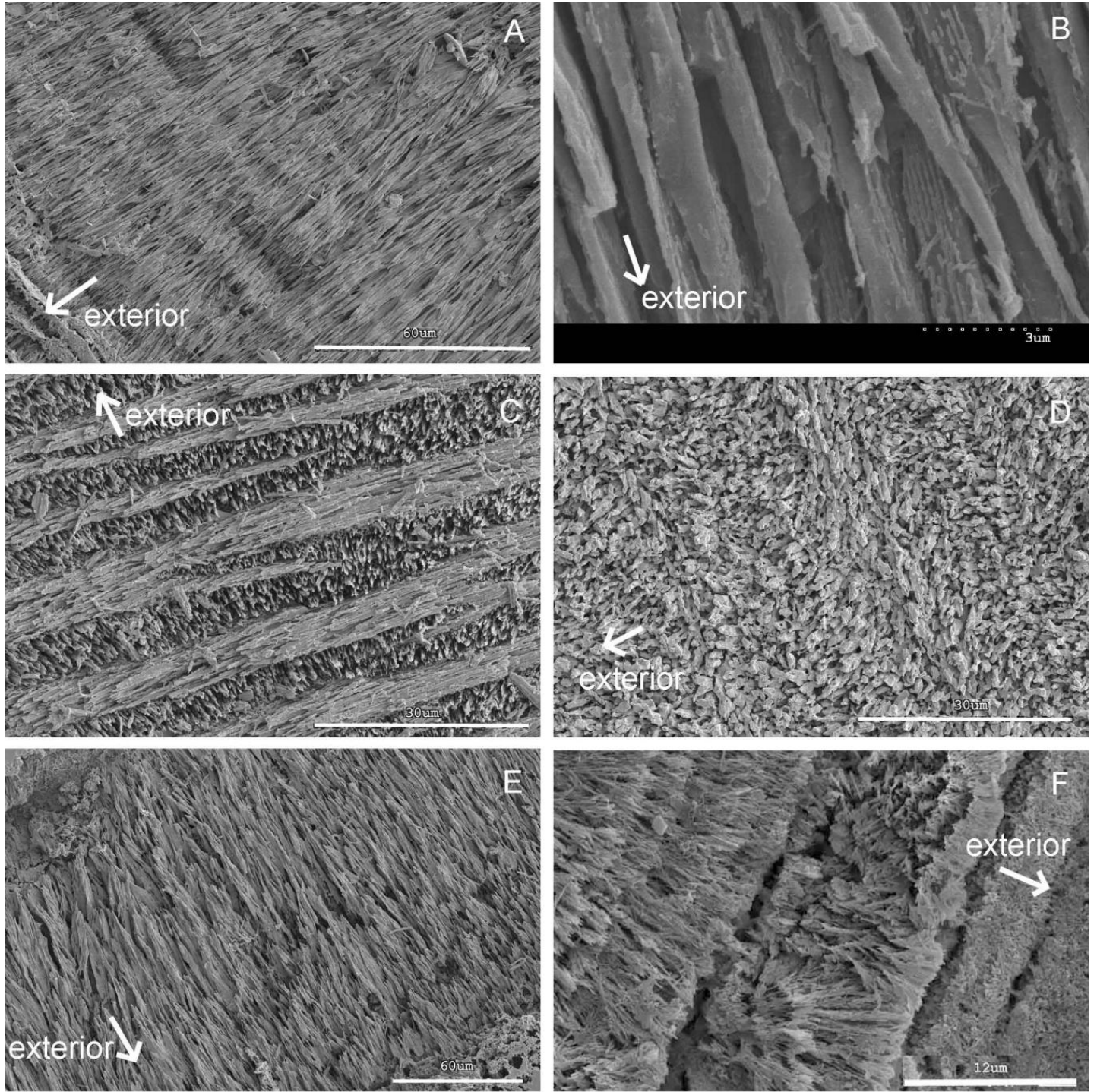

Figure 2. (A) Transverse section of irregular spherulitic prismatic structure in Pyrgopolon mellevillei from the Eocene of England. (B) Transverse section of regularly ridged prismatic structure (RRP) in Miocene D. gracillima. (C) Longitudinal section of twisted plywood structure in Spiraserpula sp. from the Miocene of Austria. (D) Longitudinal section of lamello-fibrillar structure in Rotularia nummularia (Eocene, Italy). (E) Longitudinal section of spherulitic prismatic structure in Glomerula sp. (Upper Cretaceous, Germany). (F) Longitudinal section of spherulitic prismatic structure in Diplochaetetes mexicanus from the Oligocene of Mexico.

(8) The regularly ridged prismatic structure (RRP) is characterized by ridged lateral surfaces of the calcitic prisms, which interlock the prisms together [22]. The RRP structure occurs exclusively in the genus Ditrupa (Figure 2B). 
(9) The plywood structure is composed of long fiber-like crystallites, which have a common orientation within each growth increment but a different orientation in adjacent growth increments. Nevertheless, the acute angle between the orientations of differently oriented fiber-like crystallites is fixed across the growth increments (Figure 2C).

(10) The lamello-fibrillar structure [1] is composed of prismatic crystallites, which have a common orientation within each growth increment but a different orientation in adjacent growth increments. The orientation of crystallites in successive laminae differ by irregularly varying angles (Figure 2D).

\subsection{Mineral Composition}

The mineral composition is known only in few fossil serpulids. Fossil serpulid tubes are either calcitic or aragonitic. Tubes with mixed composition are not known. Tubes of fossil Ditrupa have a calcitic composition [22]. Purely aragonitic tubes occur in "Serpula" etalensis from the Lower Jurassic of Germany [21]. In "Serpula" etalensis, X-ray diffraction analyses showed pure calcitic composition for Upper Sinemurian specimens from southwestern Germany, and pure aragonitic composition for younger specimens (Upper Pliensbachian specimens from eastern Germany) [21]. The mineral composition of the majority of fossil serpulid tubes is not known, but considering the preservation issues it is likely that most Mesozoic serpulid fossils had a calcitic composition.

\section{Biomineralization of Fossil Sabellids}

\subsection{Skeletal Structures}

Skeletal microstructures of just two species of fossil sabellids have been described [2]. Both Glomerula sp. (Jurassic, Germany) and Glomerula sp. (Upper Cretaceous, Germany) are single layered and have a spherulitic prismatic structure [2]. The growth lamellae are subparallel to the tube wall. Unlike the recent G. piloseta, the thin, friable outer layer with spherulitic structure, if it was ever present, is not preserved in the tube wall of Jurassic and Cretaceous Glomerula [2]. The prisms show growth lamellae, but are continuous through the multiple growth lamellae and through the entire tube wall [2] (Figure 2E).

\subsection{Mineral Composition}

The mineral composition of fossil sabellid tubes has not been studied. The tube microstructure of some fossil sabellids looks like aragonite, but there is no confirmation by XRD [2]. On the other hand, aragonite has a poor preservation potential, but both studied fossil sabellids have well preserved original tube microstructures. Thus, one cannot exclude the possibility of original calcitic mineralogy of Mesozoic sabellid tubes.

\section{Biomineralization of Fossil Cirratulids}

\subsection{Skeletal Structures}

Only the fossil cirratulid with known skeletal structure, Diplochaetetes mexicanus from the Oligocene of Mexico [5], has a lamellar tube structure, mostly with a spherulitic prismatic microstructure [3]. In addition to the spherulitic prismatic structure, there are also lamellae with a homogeneous structure composed of unoriented calcareous rods in the tube wall of D. mexicanus [3]. In D. mexicanus, spherulitic prisms are often epitaxially continuous through several growth lamellae [3]. Spherulites have also been reported from the tube walls of all D. mexicanus, but they do not form distinct layers occurring within the lamellae of a spherulitic prismatic structure [3] (Figure 2F). 


\subsection{Mineral Composition}

Raman spectroscopy, supported by EDX, has confirmed the pure aragonitic mineralogy of fossil cirratulid worm tubes belonging to Diplochaetetes mexicanus [24]. The mineral composition of Diplochaetetes mexicanus is identical to the recent species Dodecaceria caulleryi and Dodecaceria coralii [24].

\section{Discussion}

\subsection{Interpretation of Fossil Skeletal Structures and Fossilization Microstructures}

The fossil skeletal microstructures of calcareous polychaetes show various states of preservation. In many cases, the original tube microstructures are well preserved, as indicated by the preservation of growth increments and sometimes even by the substructure of primary crystallites. In other cases, the original microstructures have been completely substituted by diagenetic fabrics. Most likely, the fine homogeneous granular structure is a completely diagenetic fabric as it is common in older Mesozoic fossils [20] and not known in any recent serpulid [1]. Spherulitic prismatic structures may also in some cases be diagenetic [20], especially when they are found as irregular intercalations within the other fabrics. The diagenetic nature of the coarse angular crystal homogeneous microstructure is also likely when it lacks preserved growth increments such as in the case of Filogranula tricristata from the Bajocian of Switzerland [20]. The other above-described serpulid microstructures are either preserved in their original state or show little diagenetic alternation. In general, Cenozoic serpulid microstructures are better preserved than older Mesozoic serpulid structures. One would also expect that the original aragonitic structures are seldom preserved, considering the poor stability of this biomineral and being substituted by more stable calcitic secondary structures. In contrast to serpulids, no secondary diagenetic structures have been found in fossil sabellids and cirratulids. The latter may well be due to sampling bias as only a few fossil tube samples of sabellids and cirratulids have ever been studied.

\subsection{Comparison of Fabrics of Skeletal Microstructures in Calcareous Polychaetes}

Fabrics of skeletal microstructures of serpulids, sabellids and cirratulids show great differences, especially in the diversity of produced microstructures. Sabellids and cirratulids are similar in their ability to build microstructures; they have both just exploited a single way in the construction of tube microstructures. On the other hand, serpulids have about ten-fold more diverse fabrics of tube microstructures than sabellids and cirratulids. Similarly, the complexity of serpulid tube microstructures is different from that of sabellids and cirratulids. Serpulids are able to build complex tube microstructures such as a regularly ridged prismatic structure, twisted plywood structure and lamello-fibrillar structure, which have comparable complexity to complex structures of molluscs and arthropods [27]. In contrast, sabellids and cirratulids are only able to build a spherulitic prismatic structure, which is one of the most primitive skeletal microstructures.

\subsection{Evolution of Skeletal Structures}

There has not been much evolution in skeletal structures of sabellids from the Jurassic to the Qauternary, since they all have similar tube microstructures [2] (Figures 3 and 4). Similarly cirratulid skeletal structures have not changed much since the Oligocene [3] (Figures 3 and 4). On the other hand, serpulid skeletal structures have greatly diversified and evolved in complexity from the Jurassic to the Quaternary (Figures 3 and 4). Despite the potential preservation issues, Mesozoic serpulids [20] had obviously less diverse fabrics of tube microstructures than Cenozoic serpulids $[18,19]$. The same is true for the complexity of serpulid skeletal microstructures. The first complex serpulid tube structures such as the regularly ridged prismatic structure in Ditrupa and the lamello-fibrillar structures in Rotularia spirulaea and R. nummularia appeared in the Eocene $[19,22,23]$. The evolution of serpulid tube structures can be explained by the importance of calcareous tubes for serpulids as a taxon. Calcareous tubes have played an important role for serpulids as protection against predators and environmental 
disturbances throughout their evolution. The conservative biomineralization strategies of sabellids and cirratulids may result from the unimportance of biomineralization in their evolution as only few species of sabellids and cirratulids have ever built calcareous tubes. The diversity of recent serpulids, sabellids and cirratulids is comparable and the relative diversities of these groups are likely not behind the differences in their biomineralization strategies.

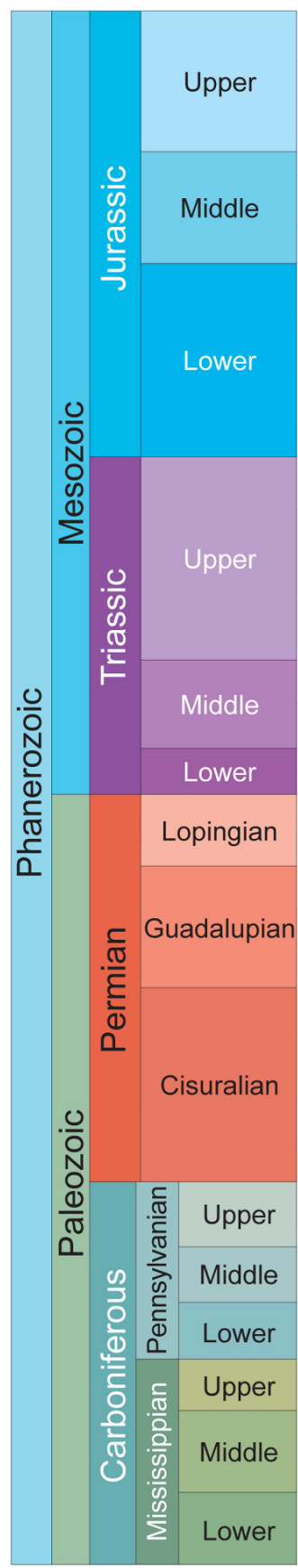

Serpulidae

Sabellidae
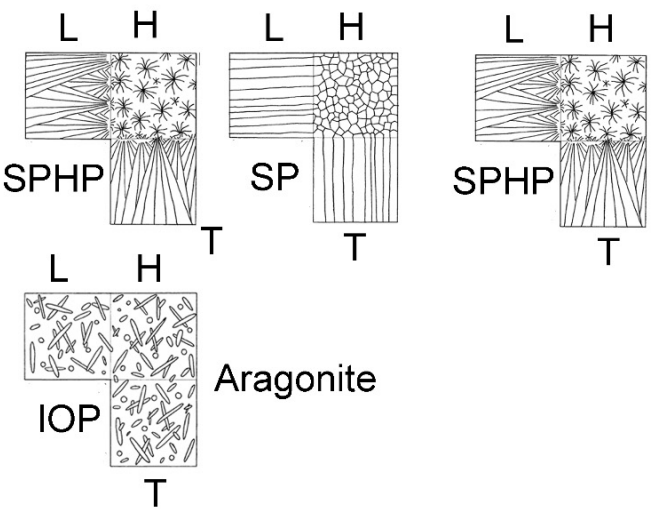

First serpulids First sabellids

Figure 3. First appearances of tube microstructures and mineral composition in calcareous polychaetes (Permian to Jurassic). IOP-irregularly oriented prismatic structure, SPHP-Spherulitic prismatic structure, SP-simple prismatic structure. Stratigraphy modified based on the International Stratigraphic Chart [28]. 


\subsection{Evolution of Mineral Composition}

There are few data available on the evolution of mineral composition in calcareous polychaetes. Cirratulids have always been aragonitic throughout their evolution [24]. The evolution of mineralogical composition in sabellids is not known, but they are aragonitic in modern seas [2]. The first purely aragonitic serpulids are known from the Jurassic [21]. Calcitic serpulids with prismatic structures likely occurred already in the Jurassic based on the similarity of their skeletal structures to modern calcitic prismatic serpulid structures. The mineral composition of modern serpulid tubes has been reported to be either calcitic, aragonitic or a combination of both polymorphs [29-32]. All recent purely calcitic and dominantly calcitic serpulid species [1,30] form the terminal branch of the phylogenetic tree [33] and serpulids in their sister clade have aragonitic tubes [25]. Thus, one can hypothesize that the first serpulids were aragonitic when they appeared in the aragonitic seas of the Permian and Triassic, whereas the appearance and major diversification of calcitic species took place in the calcitic seas of the Jurassic and Cretaceous.

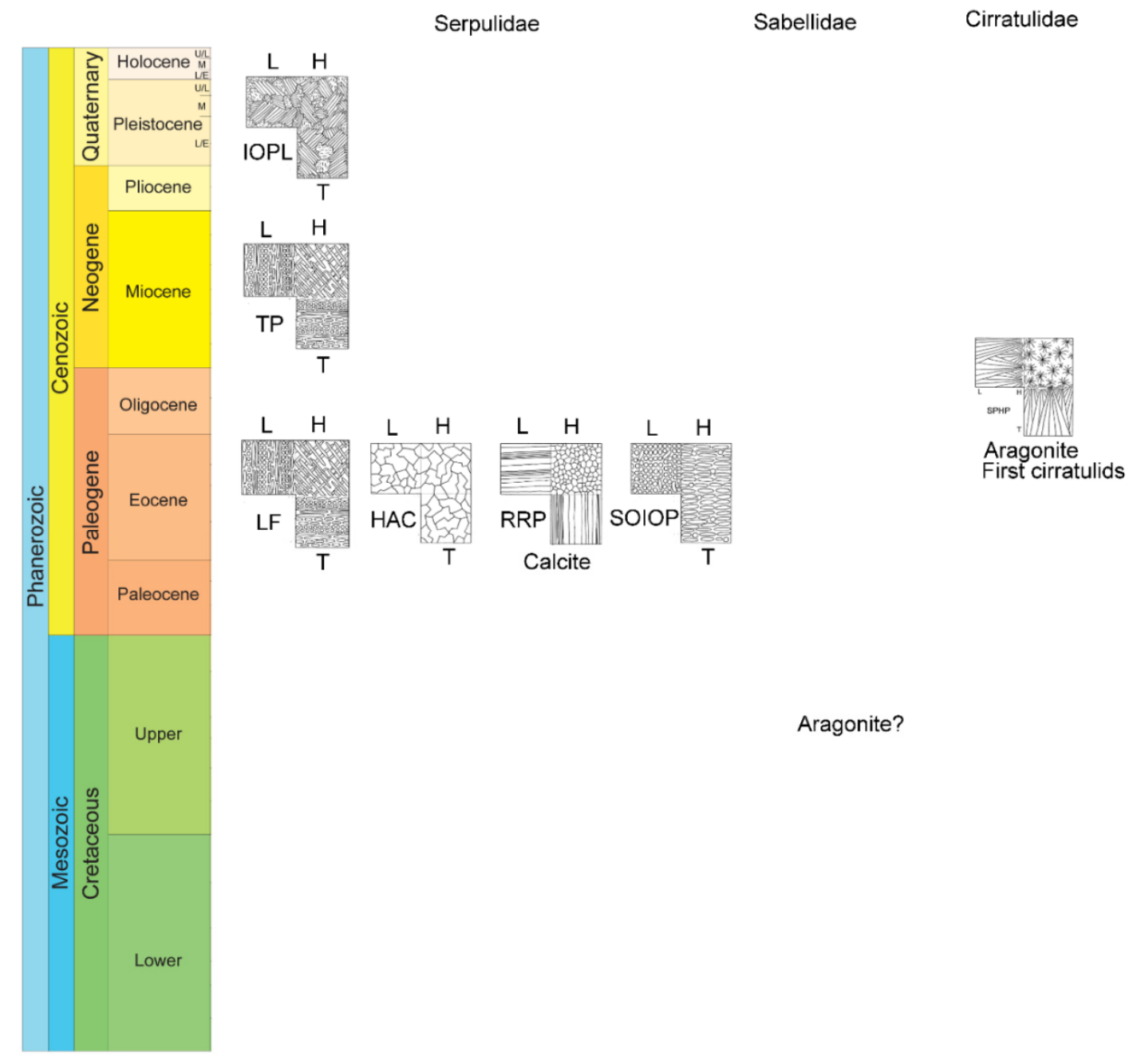

Figure 4. First appearances of tube microstructures and mineral composition in calcareous polychaetes (Cretaceous to Quaternary). IOP_irregularly oriented prismatic structure, SPHP-Spherulitic prismatic structure, $\mathrm{SP}$ - simple prismatic structure, LF-lamello-firbrillar structure, HAC-Homogeneous angular crystal structure, RRP-Regularly ridged prismatic structure, TP-twisted plywood structure, SOIOP_semi-ordered irregularly oriented prismatic structure, IOPL_irregularly oriented platy structure. Stratigraphy modified based on the International Stratigraphic Chart [28]. 
Funding: Financial support to O.V. was provided by Estonian Research Council grant IUT20-34.

Acknowledgments: O.V. is thankful to the Naturalis Biodiversity Center, Natural History Museum Vienna, Berlin Museum of Natural History, Paleontological Institute and Museum, University of Zurich for providing access to their fossil polychaete collections. The author is also grateful to two anonymous reviewers for the constructive reviews.

Conflicts of Interest: The author declares no conflict of interest.

\section{References}

1. Vinn, O.; Ten Hove, H.A.; Mutvei, H.; Kirsimäe, K. Ultrastructure and mineral composition of serpulid tubes (Polychaeta, Annelida). Zool. J. Linn. Soc. 2008, 154, 633-650. [CrossRef]

2. Vinn, O.; Ten Hove, H.A.; Mutvei, H. On the tube ultrastructure and origin of calcification in sabellids (Annelida, Polychaeta). Palaeontology 2008, 51, 295-301. [CrossRef]

3. Vinn, O. The ultrastructure of calcareous cirratulid (Polychaeta, Annelida) tubes. Est. J. Earth Sci. 2009, 58, 153-156. [CrossRef]

4. Sanfilippo, R.; Rosso, A.; Reitano, A.; Insacco, G. First record of sabellid and serpulid polychaetes from the Permian of Sicily. Acta Palaeontol. Pol. 2017, 62, 25-38. [CrossRef]

5. Fischer, R.; Pernet, B.; Reitner, J. Organomineralization of cirratulid annelid tubes-fossil and recent examples. Facies 2000, 42, 35-50. [CrossRef]

6. Bandel, K. The reconstruction of "Hyolithes kingi" as annelid worm from the Cambrian of Jordan. Mitt. Geol.-Paläontol. Inst. Univ. Hamburg 1986, 61, 35-101.

7. Zibrowius, H.; ten Hove, H.A. Neovermilia falcigera (Roule, 1898), a deep- and cold-water serpulid polychaete common in the Mediterranean Plio-Pleistocene. Bull. Biol. Soc. 1987, 7, $259-271$.

8. Hove, H.A.T.; Smith, R.S. A re-description of Ditrupa gracillima Grube, 1878 (Polychaeta, Serpulidae) from the Indo-Pacific, with a discussion of the genus. Rec. Aust. Mus. 1990, 42, 101-118. [CrossRef]

9. Sanfilippo, R.; Mòllica, E. Serpula cavernicola Fassari and Mòllica, 1991 (Annelida Polychaeta): Diagnostic features of the tubes and new Mediterranean records. Mar. Life 2000, 10, $27-32$.

10. Sanfilippo, R. Additional notes on the little known serpulid Serpula israelitica Amoreux, 1976 and new Mediterranean records. In Atti III Giornate di Paleontologia Maggio; Società Paleontologica Italiana: Modena, Italy, 2003.

11. Nishi, E. On the internal structure of calcified tube walls in Serpulidae and Spirorbidae (Annelida, Polychaeta). Mar. Foul. 1993, 10, 17-20. [CrossRef]

12. Sanfilippo, R. Spirorbid Polychaetes as boreal guests in the Mediterranean Pleistocene. Riv. Ital. Paleontol. Strat. 1998, 104, 279-286.

13. Sanfilippo, R. Ditrupa brevis n.sp., a new serpulid from the Mediterranean Neogene with comments on the ecology of the genus. Riv. Ital. Paleontol. Strat. 1999, 105, 455-464.

14. Weedon, M.J. Tube microstructure of Recent and Jurassic serpulid polychaetes and the question of the Palaeozoic 'spirorbids'. Acta Palaeontol. Pol. 1994, 39, 1-15.

15. Senowbari-Daryan, B. Barbafera carnica Senowbari-Daryan, 1980: A Triassic Worm-tube. Facies 1997, 36, 57-68. [CrossRef]

16. Vinn, O. The tube ultrastructure of serpulids (Annelida, Polychaeta) Pentaditrupa subtorquata, Cretaceous, and Nogrobs cf. vertebralis, Jurassic, from Germany. Proc. Est. Acad. Sci. Geol. 2005, 54, 260-265.

17. Taylor, P.D.; Vinn, O. Convergent morphology in small spiral worm tubes ('Spirorbis') and its palaeoenvironmental implications. J. Geol. Soc. 2006, 163, 225-228. [CrossRef]

18. Vinn, O. Taxonomic implications and fossilization of tube ultrastructure of some Cenozoic serpulids (Annelida, Polychaeta) from Europe. Neues Jahrb. Geol. Paläontol. 2007, 244, 115-128. [CrossRef]

19. Vinn, O. Tube ultrastructure of the fossil genus Rotularia Defrance, 1827 (Polychaeta, Serpulidae). J. Paleontol. 2008, 82, 206-212. [CrossRef]

20. Vinn, O.; Furrer, H. Tube structure and ultrastructure of serpulids from the Jurassic of France and Switzerland, its evolutionary implications. Neues Jahrb. Geol. Paläontol. 2008, 250, 129-135. [CrossRef]

21. Vinn, O.; Jäger, M.; Kirsimäe, K. Microscopic evidence of serpulid affinities of the problematic fossil tube "Serpula" etalensis from the Lower Jurassic of Germany. Lethaia 2008, 41, 417-421. [CrossRef] 
22. Vinn, O.; Mutvei, H.; Ten Hove, H.A.; Kirsimäe, K. Unique Mg-calcite skeletal ultrastructure in the tube of the serpulid polychaete Ditrupa. Neues Jahrb. Geol. Paläontol. 2008, 248, 79-89. [CrossRef]

23. Buckman, J.O. The tube of Ditrupa bartonensis (Annelida, Serpulidae), from the Eocene of southern England: Observations on microstructure and its significance. Palaeontol. Electr. 2020, 23, a37. [CrossRef]

24. Taylor, P.D.; Vinn, O.; Kudryavtsev, A.; Schopf, J.W. Raman spectroscopic study of the mineral composition of cirratulid tubes (Annelida, Polychaeta). J. Struct. Biol. 2010, 171, 402-405. [CrossRef] [PubMed]

25. Smith, A.M.; Riedi, M.A.; Winter, D.J. Temperate reefs in a changing ocean: Skeletal carbonate mineralogy of serpulids. Mar. Biol. 2013, 160, 2281-2294. [CrossRef]

26. Vinn, O.; Hryniewicz, K.; Little, C.T.S.; Nakrem, H.A. A Boreal serpulid fauna from Volgian-Ryazanian (latest Jurassic-earliest Cretaceous) shelf sediments and hydrocarbon seeps from Svalbard. Geodiversitas 2014, 36, 527-540. [CrossRef]

27. Carter, J.G.; Bandel, K.; de Buffrenil, V.; Carlson, S.J.; Castanet, J.; Crenshaw, M.A.; Dalingwater, J.E.; Francillion-Vieillot, H.; Geradie, J.; Meunier, F.J.; et al. Glossary of Skeletal Biomineralization. In Skeletal Biomineralization: Patterns, Processes and Evolutionary Trends; Carter, J.G., Ed.; Wiley: Hoboken, NJ, USA, 1990; pp. 609-671.

28. The International Stratigraphic Chart. 2020. Available online: https://stratigraphy.org/icschart/ ChronostratChart2020-03.pdf (accessed on 1 March 2020).

29. Lowenstam, H.A. Environmental relations of modification compositions of certain carbonate secreting marine invertebrates. Proc. Natl. Acad. Sci. USA 1954, 40, 39-48. [CrossRef]

30. Bornhold, B.D.; Milliman, J.D. Generic and environmental control of carbonate mineralogy in serpulid (Polychaete) tubes. J. Geol. 1973, 81, 363-373. [CrossRef]

31. Simkiss, K.; Wilbur, K.M. Biomineralization: Cell Biology and Mineral Deposition; Academic Press: San Diego, CA, USA, 1989; p. 337.

32. Vovelle, J.; Grasset, M.; Truchet, M. Sites of biomineralization in the polychaete Pomatoceros triqueter (Serpulidae) with comments on some other species. In Systematics, Biology and Morphology of World Polychaeta: Proceedings of the 2nd International Polychaete Conference Copenhagen 1986; Petersen, M.E., Kirkegaard, J.B., Eds.; Ophelia: Malmö, Sweden, 1991; Volume 5, pp. 661-667.

33. Kupriyanova, E.K.; Macdonald, T.A.; Rouse, G.W. Phylogenetic relationships within Serpulidae (Sabellida, Annelida) inferred from molecular and morphological data. Zool. Scr. 2006, 35, 421-439. [CrossRef] 